\title{
Prospects for the interdisciplinary role of English studies in South African universities
}

\author{
E. R. Jenkins \\ Head Office \\ Vista University \\ PRETORIA
}

\begin{abstract}
Dehate on the nature of English studies in South Africa has not produced an indication of a way fonvard. Since English became a school and university subject, its contents and aims have never been fixed for long. This paper proposes that the indeterminate nature of the subject should be exploited by seeking new ways for English to interact with other disciplines. English has a reciprocal relationship with other disciplines, most notably philosophy: but to call it a science is to take it into a dead end. In South Africa, contested areas of subject matter are the nature of English as spoken by and taught to non-mother tongue speakers, and the metropolitan/colonial literature distinction. English should join other disciplines in exploring new aesthetic and philosophical paradigms that reflect the country's multicultural composition. A new approach to curriculum theory for universities is needed to explore interdisciplinary cooperation. The complexity of South African society also requires new teaching methods across the disciplines.
\end{abstract}

\section{The failure of the inward-looking debate}

In 1989 the English Academy of Southern Africa held a conference on "English at Tertiary Level", to examine the nature of English studies in South African tertiary education institutions. Malvern Van Wyk Sinith's paper on English in South African universities, published as "Pressures and Models: Rethinking English Studies" (1990), concentrated, as his title indicates, on the curriculum of English departments - on such matters as literary canon, the integration of literary and linguistic studies, the benefits to the student of taking up English studies, and how departments were to cope with an influx of non-English speakers. He also mentioned the pressure for English departments to offer academic support programmes as a service to the rest of the university. Three years later, after listening to speakers at the English Academy conference on "Access to English", Van Wyk Smith remarked that the debate had not advanced one jot since 1989. 
It is inevitable that as long as English academics confine discussion on the future of English studies in South Africa to a navel-contemplating, circular argument about the nature and aims of English studies, nothing helpfully new is going to emerge. Certainly, as the "Access to English" conference showed, issues related to languages and literature in South Africa are in turmoil at present, and rethinking is necessary. In this paper I argue that we should, in the post-modernist spirit of the times, take advantage of the slippery, shifting nature of English studies to consider, rather, the boundaries of the discipline, and look at the possibilities that lie in the overlapping and merging of English studies and other disciplines as a way forward for the disciplines of language and literature in South African universities.

\section{English studies and related disciplines}

In a rough and ready way, most people know what they mean when they speak of English as a university discipline. However, if we want to consider the interdisciplinary role of English, it is necessary to inquire whether English has any boundaries - and this is not a simple task.

What 'English' are we to talk about? Apart from whatever it is they do in English departments, we cannot overlook other university departments that make English, or aspects of English, the object of study: linguistics, applied linguistics, methodology of teaching English as mother tongue, methodology of teaching English to speakers of other languages, professional communication, English for special purposes, adult literacy, drama, media studies, journalism, lexicography, translation, creative writing (in American university English departments), homiletics in schools of divinity, aspects of psychology such as language acquisition and speech disorders, aspects of philosophy such as logic, and academic support programmes. To this list, which is bound to be incomplete, must be added English as the medium of communication in English-medium universities, the concern of everyone from the young student struggling with unfamiliar academic discourse to the vice-chancellor in his office privately rehearsing his graduation address.

In trying to bring some tidiness to this scene, it cannot be supposed that there was a kind of ur-English department from which all these other disciplines have broken off. English never was a unitary subject, and its history as an academic discipline is one of merging and fragmenting of components. The earliest appearance of English in university curricula was in the form of the philological study of Old English (Palmer, 1965). After the study of literature written in modern English has been introduced, nobody could agree on how it was to be taught in an academically respectable way, nor could language and literature comfortably collabit in the same department. Modern English language as an object of study was kept out of most South African English departments, although English lec- 
turers still had to teach their students how to use English. However, with the rapid increase of speakers of other languages taking English at university, we are witnessing far more attention to the teaching of language skills in undergraduate English classes, although at some universities this responsibility has been transferred to other academic departments with other names. This does not include the need for English to be taught as an enabling, or service subject in universities where English is the medium of instruction. In the past, this duty has often been delegated to English departments in the guise of having to teach a compulsory English course called something like 'Practical English', but nowadays special departments such as Academic Skills sections deal with this, and this work can be expected to expand yet further in the future.

The definition of the school subject of English, on which university teaching presumably has to build, has not been any simpler: the history of the school subject shows it to have been a constellation of subjects with shifting objectives and subject matter. (See Jenkins, 1973, on the secondary school, and Harley, 1991, on the primary school.) A dialectic exists between English in school and in the university: usually, changes in the university subject such as fashions in prescribed authors have affected the school subject, but universities are increasingly having to accommodate the background and skills of students produced by poor secondary schooling.

\section{The links of English studies with other disciplines}

The university subjects listed above are the siblings, clones and offspring of English, whose affinities are demonstrable. English also has its peers, in the form of the other university subjects, with some of which it has a relationship that is much more complex than its relationship with the other language-based subjects. Some of these links are historical, but often they are sporadic, or subject to fashion, and they can best be classed as unpredictable, which makes it difficult to predict how the disciplines will draw on or influence each other in the future. Some examples will, perhaps, give an indication of possible trends.

A discipline which gave new insights into literature early in the twentieth century was psychology. In the field of children's literature, for example, it is difficult to imagine writing criticism of children's books before the work of Freud and Jung became known. Although as undergraduates at the University of Natal in the 1950s we were forbidden by our English professor, a product of the Leavis school, to use psychological terns, one can now go back to Jung and see how many terms he coined, such as psychic energy and collective unconscious, that are now common currency in any educated discourse. Psychology has continued to feed its insights into literary criticism: the work of Lacan actually merges the two disciplines. Developments such as post-Lacanian psychoanalysis indicate 
that the interplay of English studies and psychology will probably be one of the most fruitful forms of interdisciplinary cross-fertilization in the next few years.

Another twentieth century discipline that is closely linked with literary criticism is anthropology, which, in the 1960s, took up Saussure's linguistic structuralism and endeavoured to make it the basis of a new theoretical way of analysing human activities and constructs. "[Structuralism] is a symptom of the fact that language, with its problems, mysteries and implications, has become both paradigm and obsession for twentieth-century intellectual life", remarks Terry Eagleton (1983: 97). However, because structuralism is ultimately merely descriptive, it does not have the dynamic potential that the link between psychology and English studies has, and it has become a dead-end in both anthropology and literary criticism.

Historiography has become closely linked with literary criticism in recent years. Revisionist historiograplyy of the colonial period in Southern Africa has led to the rewriting of the history of South African literature based on the new paradigms provided, such as Van Wyk Smith's Grounds of Contest, with its theme of 'appropriation and resistance' (1990:66), and Haarhoff's history of the literature of Namibia, The Wild South-West (1991), which borders on history through its focus on the theme of 'frontier' and its use of non-fictional source materials. A key period in the history of Natal has been rewritten by two lecturers of English who have analysed the original documents of white men who knew Shaka: Stephen Gray on 'Joln Ross' (1992) and Dan Wylie on Nathaniel Isaacs (1991).

Studies in the history of colonialism, especially its human rather than political character, have been, and still are, largely the work of literary scholars such as Edward Said and Gayatri Spivak. South Africa, in its materials and its literary scholars, has an important contribution to make. Significantly, the Thomas Pringle Prize for the best literary article published in this country in 1988-1989 was awarded by the English Academy to Dorothy Driver for her article "'Woman' as Sign in the South African Colonial Enterprise" (1988), the judges having commended it for its contribution to the topic.

Biography, which has been the subject of intense theoretical study by a school of literary theorists, is an important genre of modern South African literature, since a great deal of autobiographical and semi-autobiographical material has been and is being produced by and about black people. Literary criticism of these works inevitably incorporates historical and political analysis. Looking to the future, one may forecast that revisionist historiography still has much to say about the South African past, and that literary studies will both learn from and contribute to this process

In the history of ideas, movements whose time has arrived affect a wide variety of disciplines. Feminism is an example: as a way of looking at things, it impinges 
upon English, and English studies are making a significant contribution to refining theory in the field. In addition, critics such as Driver have already made incisive contributions to the study of South African literature and society through the application of feminist theory. This shows how new theories may in the future bring about revelations in a country so long dominated by a restricted range of ideologies.

The most productive interdisciplinary exchange in English studies has been, and will continue to be, between literary theory and philosophy. Of course, English is only one of nany languages whose scholars contribute to this exchange. Since to talk of 'philosophy' is too general, it might be more precise to talk of topics within philosophy.

Marxist literary theory is a good example of how a special sub-set of a broader theory can be devised for literature. Though in its pure form it is no longer much applied, it has had a lasting effect in producing critics who place literature in its social context. In South Africa, most contemporary criticism of English literature incorporates this approach; however, the potential of Marxist theory for uncovering the social processes which govern the means of production of, and access to, literature in South Africa has not yet been fully exploited, and we can expect more fruitful research in this field.

Hermeneutics in a broad sense, rather than as specifically a German school of philosophy, underlies the epistemological concerns of modern literary theory. English has shared with philosopliy, and the philosophy of science, the debate of the last twenty or thirty years on the nature of reality and meaning. Ethnomethodology, quantum physics, phenomenology and the reception-aesthetics of Wolfgang Iser of the 1970s (e.g. Iser, 1978) have been succeeded, almost inevitably, by various post-modernisms which propound a world of "an unlimited number of models of order" embedded in different "communit[ies] of meanings": "from the post-modern point of view relativity of knowledge ... is a lasting feature of the world" (Bauman, 1987:4).

The movement of ideas is not only in one direction, from philosophy to literary studies; witness Derrida's deconstructionist assault on philosophy through literary criticism. What Jonathan Culler (1987:28) says about the contribution of literary studies in the USA is probably true in general:

Many of the most interesting and innovative developments in modern thought have been taken up here not by philosophers but by literary critics and have entered American intellectual life through the field of literary studies.

Culler's observation has recently been reiterated by Morris Dickstein (1992:17): 
Prospects for the interdisciplinary role of English studies in South African universities

Not since Mencken and Van Wyck Brooks have American critics been such superstars, in demand on talk shows and the lecture circuit. Philosophers like Richard Rorty and Stanley Cavell, historians like Hayden White, and anthropologists like Clifford Geertz pay tribute to critics for doing what philosophers and social thinkers should be doing.

In his latest book, Stanley Fish (1989), a leading American literary scholar, has usefully extended his theories on cognitive relativism in literature to legal studies. Fish is part of a movement that questions a neat distinction between arts and reality, but unlike Derrida he believes that "there is no subjectivist reading because the observer is never individual in the sense of unique or private" meaning is the product of "the local, the historical, the contingent, the variable, the rhetorical" (Fish, 1989:83, 345). In this way he sees literary criticism as sharing common concerns with other disciplines which are questioning the Kantian approach to rationality. Literary historians, for example, no longer go for the broad sweep of trends, and one sees the same approach in historians of art and science.

\section{English studies and 'science'}

While the rest of the world is being enriched by discovering the 'literariness' of non-literary disciplines (Culler, 1987:30), a naive conviction persists in some quarters that not only is empirical science value-free, but that the humanities can also be reduced to a 'science'. An extraordinary example of this with an important Southern African connection was the huge, long-awaited first volume of Harald Pager's The Rock Paintings of the Upper Brandberg, published in 1989. In this book the paintings are analysed by Tilman Lenssen-Erz according to a model based on a putative linguistic structure which turns out to be a rather inaccurate and highly simplified version of the grammar of the basic English sentence. Presumably he derived the notion from an over-enthusiastic appreciation of the contribution that semiotics, which had its origin in linguistics, has made to other disciplines, including the study of the creative arts - a symptom of the intellectual's obsession with language referred to earlier. He claims that his model gives his analysis empirical accuracy, but, as Lewis-Williams (1990) has shown, this is one case where the interdisciplinary contribution of English is a mismatch.

In South Africa, the tern science still enjoys exaggerated respect, in spite of increased awareness of the "impossibility of a value-neutral science" (Jansen, 1991:20). As recently as 1991, the division of the Human Sciences Research Council responsible for promoting research in the humanities changed its name to the Centre for Science Development. This is simply another manifestation of the "so-called legitimation crisis in the human sciences" which McGann (1989:2) 
describes as "irrelevant", as it promotes a view of science that Eagleton calls "a straw target, ... this caricature of scientific self-reflection" (1983:144).

It is difficult to see how English can benefit from this artificial attempt to call it a 'science'. The efforts of the HSRC to define the humanities in positivist terms have serious implications. One of these is to deny the very approach which, as Dickstein (1992:17) has pointed out, is the unique contribution that literary critics are at present making to scholarship: "raising the right questions, self-consciously refining their techniques, undermining the dubious scientism and pseudoobjectivity that still holds sway in other fields." It will be the responsibility of English scholars to continue this questioning role in South African scholarship.

The other implication of the HSRC's defining activities may be deduced from considering how the nature of knowledge is related to the relationship between knowledge and power: how "those in power have the ability to define appropriate knowledge through the various chanmels available to them (the control of research institutions and funding agencies, for example)" (Jansen, 1991:20). It is not going to put the activities of the HSRC beyond political dispute simply to call them 'scientific'.

\section{Defining appropriate knowledge}

In the field of English, argument over defining appropriate knowledge focuses on two areas. The first is the labelling of certain language courses as 'English Second Language' or 'Practical English'. Although in the rest of the world the teaching of English to speakers of other languages is a huge, recognized industry, the terms second and practical are offensive in South Africa because of the historical connotations of second-class citizenship and Bantu Education, seen to be restricted to training for manual labour. Those responsible for the teaching of English in South Africa face the acute challenge of offering this highly desirable commodity in such a way as to avoid connotations of neo-colonialism.

The second debate on defining appropriate knowledge deals with the literary canon, or at any rate, the selection of prescribed texts. This is equally politically sensitive, fixing as it does upon the metropolitan/colonial distinction, with its connotations of colonial subjugation. Although South African literature has been prescribed in local syllabuses for many years - a South African book was prescribed by the Transvaal Education Department as far back as 1946 - English departments are still regularly accused of maintaining a Eurocentric hegemony over their syllabuses. Mokubung Nkomo (1991:311) makes the valid point that the marginalizing of black South Africans - and women too, incidentally - is paralleled "in the establishınent, at a few of the universities, of African Studies and Women [sic] Studies Departments (usually groups that are not part of the norm 
are the objects of anthropological, sociological studies or in such courses as Bantu Law and Administration)". The fresh approach that black scholars such as Nkomo are calling for is that we move away from the numbers game of calculating what percentage of academic syllabuses or curricula is devoted to 'African' material, to an approach that employs the aesthetics and methods of interpretation of various cultures. Lewis Nkosi (1992:33) explains,

I do feel a lot of the critical equipment that is available in Europe or in America can still be adapted for local use. I don't believe that there is anything wrong with, for example, using deconstruction in order to read our own texts ... . We should be so eclectic that we should borrow methods of reading, methods of interpretation from whatever culture, if it is going to make us gain access to a text and to re-read it in a way that it has never been read before.

A similar argument is made by Cecil Bodibe (1992) for a new approach to psychological counselling in South Africa. Such calls have both justice and need on their side, though the argument will have to be refined much further. What is needed is an investigation in which the disciplines involved - English and Afrikaans, history, philosophy, psychology and the creative and performing arts would share their resources to promote a movement of renewal in our universities.

Such an endeavour to redefine the centre should not be confused with shallow attempts to make syllabuses 'p.c.' - 'politically correct'. Robert Hughes argued in a recent essay in Time (1992:54) that trivial, knee-jerk fads and fashions end up missing the real point:

In the late $80 \mathrm{~s}$, while American academics were emptily theorizing that language and the thinking subject were dead, the longing for freedom and humanistic culture was demolishing European tyranny ... . The world changes more deeply, widely, thrillingly than at any moment since 1917 , perhaps since 1848 , and the American academic left keeps fretting about how phallocentricity is inscribed in Dickens' portrayal of Little Nell.

Obviously, a shift to what Nkomo (1991:314) calls "an inclusive scholarship as opposed to the exclusionary, Eurocentric and patriarchal mode of the traditional dominant South African epistemology" will involve interdisciplinary scholarship. An example of this is that several research projects into the history of literature in South Africa across all languages have been launched in recent years. (Recent studies that include literature of more than one language include Coetzee [1988] and Jenkins, [1993]). However, Nkomo rightly points out that little comparative linguistics is studied at South African universities, and this will have to be rectified. Already there have been calls for language associations to become more multilingual in their perspective 


\section{English and Cultural Studies}

In Britain, the locating of English in interdisciplinary studies is taking a different direction, thanks to the rise of Cultural Studies as a recognized discipline. Whereas the South African debate on the literary canon focuses on eliminating the old metropolitan/colonial distinction, the British debate arises from a socialist concern to eliminate the distinction between high and low culture. The outcome has been the formalization of what Stuart Hall has called "an area where different disciplines interact in the study of cultural aspects of society" (1980:2). Cultural Studies takes literally the theoretical view that 'literature' does not exist (Eagleton, 1983), and it has replaced literature with the mass media of popular culture. From modest beginnings when Richard Hoggart founded the Centre for Contemporary Cultural Studies at the University of Birmingham in 1964, it has now become a fully-fledged department at that university, headed by Stuart Hall, in which students may major for a degree. Much of the Centre's research has a bearing on English studies, for example in studies to distinguish fiction from nonfiction.

The greatest impact that the British Cultural Studies movement has had on South Africa has been in the inclusion of media studies in our school English syllabuses. British academics in Cultural Studies now feel in such a strong position that they are making serious calls for the subject of English to be subsumed in their wider subject, but this is not a development that we are likely to see in South Africa, at any rate for a long time. However, a broadening of the range of material studied by critics in South Africa would provide rapid dividends in our understanding of our society, as can be seen from Paul Fussell's The Great War and Modern Memory (1975) and the studies of imperialism by Joln M. MacKenzie and his colleagues at Manchester University, who include materials such as magazines and children's literature.

\section{Innovation in curriculum theory}

If universities are to exploit the interdisciplinary potential of their components, sophisticated curriculum theory must be brought to bear, which will take us beyond the mould of 'forms of knowledge' propounded by earlier curriculum theorists such as Hirst and Peters (1970). The challenge to find and service a new intellectual culture for South Africa is a complex one: I.M. Ntshoe (1991: 598), writing about the school curriculum, speaks of a need for a "significant shift from a traditionally subject-based curriculum to a curriculum that is sensitive to the political, social, and economic clianges that are occurring". In order for this change not to be an ad hoc process, it should be directed by a sophisticated theoretical approach to curriculum in the university, such as the current work of Alan 
Wilson, Vice Chancellor of Leeds University. He has devised a model for classifying academic disciplines which brings to light "quite rapid changes at the boundaries" of the disciplines and shows that "much of what is interesting involves the combination of (at first sight) disparate disciplines" (Wilson, 1992:17). By "combining different academic cultures" and "evolving new coalitions", he argues, universities will be in a position to tackle what he calls the most fruitful and important research challenge of the present, namely how to handle complexity.

He is talking mainly of mathematics and the sciences, but throws out the challenge to the arts to do the same (Wilson, 1992). South Africa certainly has complexity to offer, not least in social organization involving languages and cultures. English will have to play its part in the new combinations and coalitions needed to meet these challenges.

\section{Teaching methodology}

The way in which English studies are tauglit should be part of its contribution. In a paper delivered at the congress of the S.A. Association for Research and Development in Higher Education in 1992, Mentis and Frielich, after outlining the challenge of 'cultural diversity', 'novelty and complexity', concluded:

Mediation of challenge in the university setting includes: creating opportunities to face tasks that are unfamiliar or complicated, encouraging and rewarding risk-taking, intellectual curiosity, creativity and originality; breaking complex activities into smaller and more manageable sections; and providing a non-judgemental and supportive climate in order to facilitate experimentation.

For an approach like this to be successful, it will have to be adopted across all disciplines.

\section{References}

BAUMAN, Zygmunt. 1987. Legislators and Interpreters: on Modernity, Post-Modernity and Intellectuals. Ithaca, N.Y. : Cornell University Press.

BODIBE, R.C. 1992. Ideological Beams or Cognitive Motes? The Relevance of Counsellors in a Changing South Africa. South African Journal of Higher Fiducation.

COETZEE, J.M 1988. White Writing: on the Culture of Letters in South Africa. Sandton Radix.

CULLER, Jonathan. 1987. The Future of Criticism. (In Koelb, C. \& Lokke, V. eds. The Current in Criticism: Essays on the Present and Future of Literary Theory. West Lafayette: Purdue University Press p. 27-41.)

DICKSTEIN, Morris. 1992. Literary Critics Stage Comeback as Superstars. Times Higher Education Supplement: 17, Dec. 4. 
E.R. Jenkins

DRIVER, Dorothy, 1988. 'Woman' as Sign in the South African Colonial Enterprise. Journal of Literary Studies, 4(1):3-20, March

EAGLETON, Terry. 1983. Literary Theory: An Introduction. Oxford : Basil Blackwell.

FISH, Stanley. 1989. Doing what Comes Naturally: Change, Rhetoric, and the Practice of Theory in Literary and Legal Studies. Durham : Duke University Press.

FUSSELL, Paul. 1975. The Great War and Modern Memory. New York and London : Oxford University Press

GRAY, Stephen, ed. 1992. Charles Rawden Maclean: the Natal Papers of 'John Ross'. Pietermaritzburg : University of Natal Press

HAARHOFF, Dorian. 1991. The Wild South-West: Frontier Myths and Metaphors in Literature Set in Namibia, 1760-1988. Johannesburg: Witwatersrand University Press

HALL, Stuart ed. 1980. Culture, Media, Language: Working Papers in Cultural Studies, 1972-79. London: Hutchinson.

HARLEY, Ken. 1991. The Emergence of 'English' as a School Subject in Natal. English Academy Review, 8:1-14.

HIRST, P.H \& Peters, R.S. 1970. The Logic of Education. London : Routledge \& Kegan Paul

HUGHES, Robert. 1992. The Fraying of America. Time:52-57, Feb. 3

ISER, Wolfgang. 1978. The Act of Reading: A Theory of Aesthetic Response Baltimore Johns Hopkins University Press.

JANSEN, Jonathan D., ed. 1991. Knowledge and Power in South Africa. Johannesburg Skotaville.

JENKINS, Elwyn. 1973. The Nature of English Higher as a Secondary School Subject in the Transvaal, 1942-1972. Johannesburg : University of the Witwatersrand. (Unpublished M. Ed. dissertation.)

JENKINS, Elwyn. 1993. Children of the Sun: Selected Writers and Themes in South African Children's Literature. Johannesburg : Ravan.

LEWIS-WILLIAMS, J.D. 1990. Documentation, Analysis and Interpretation: Dilemmas in Rock Art Research. The South African Archaeological Bulletin, XLV(152): 126-136

MCGANN, Jerome J. 1989. Towards a Literature of Knowledge. Oxford : Clarendon Press.

MENTIS, M. \& FRIELICH, S. 1992. Teaching Thinking and Thinking Teaching: Adaptations of Feuerstein's Cognitive Theories in a University Setting. Paper presented at the Congress of the S.A. Association for Research and Development in Higher Education, Bloemfontein.

NKOMO, Mokubung. 1991. Epistemological and Disciplinary Transformations in a PostApartheid South Africa. (In Jansen, Jonathan D. Knowledge and Power in South Africa. p. 309-321.)

NKOSI, Lewis. 1992. Interview. (In Goddard, Kevin and Wessels, Charles, eds. Out of Exile. Grahamstown : National English Literary Museum. p. 33.)

NTSHOE, I.M. 1991. Curriculum as a Selection from Culture in Post-Apartheid South Africa. Journal of Negro Fdication, 60(4):593-601.

PAGER, H. 1989. The Rock Paintings of the Upper Brandberg. Part I: Amis Gorge. Cologne : Heinrich Barth Institute.

PALMER, D.J. 1965. The Rise of English Studies. Hull : Oxford University Press for the University of Hull.

SMITH, M. van Wyk. 1990a. Grounds of Contest: A Survey of South African English Literature. Cape Town : Juta.

SMITH, M. van Wyk. 1990b. Pressures and Models: Rethinking English Studies. (In Wright, Laurence, ed. Teaching English Literature in South Africa. Grahamstown Institute for the Study of English in Africa. p. 1-16.) 
Prospects for the interdisciplinary role of English studies in South African universities

WILSON, Alan. 1992. New Maps of Old Terrain. Times Higher Education Supplement, 17:20, May 1.

WYLIE, Dan. 1991. Autobiography as Alibi: History and Projection in Nathaniel Isaacs's Travels and Adventures in Eastern Africa. Current Writing, 3(1):71-90, Oct. 